Article

\title{
Influence of Gold on Ce-Zr-Co Fluorite-Type Mixed Oxide Catalysts for Ethanol Steam Reforming
}

Julio Cesar Vargas ${ }^{1}$, Svetlana Ivanova ${ }^{2}$, Sébastien Thomas ${ }^{3}$, Anne-Cécile Roger ${ }^{4}$ and Véronique Pitchon ${ }^{4, *}$

1 Departamento de Ingeniería Química y Ambiental, Universidad Nacional de Colombia, Ciudad Universitaria, Avenida Carrera 30 No. 45-03, Bogotá Edificio 453, Colombia;

E-Mail: jcvargass@unal.edu.co

2 Instituto de Ciencia de Materiales de Sevilla, Centro Mixto Universidad de Sevilla - CSIC, Avenida Américo Vespucio, № 49, Isla de la Cartuja, Sevilla 41092, Spain; E-Mail: svetlana@cartuja.csic.es

3 Laboratoire Catalyse et Spectrochimie, ENSICAEN, Université de Caen, CNRS, 6 Boulevard Maréchal Juin, Caen Cedex 14050,France; E-Mail: sebastien.thomas@ensicaen.fr

4 Laboratoire des Matériaux, Surfaces et Procédés pour la Catalyse, ECPM, Université de Strasbourg, CNRS, 25 rue Becquerel, Strasbourg Cedex 2-67087, France; E-Mail: rogerac@ecpm.u-strasbg.fr

* Author to whom correspondence should be addressed; E-Mail: pitchon@chimie.u-strasbg.fr.

Received: 9 January 2012; in revised form: 18 January 2012 / Accepted: 27 January 2012 /

Published: 3 February 2012

\begin{abstract}
The effect of gold presence on carbon monoxide oxidation and ethanol steam reforming catalytic behavior of two Ce-Zr-Co mixed oxides catalysts with a constant Co charge and different $\mathrm{Ce} / \mathrm{Zr}$ ratios was investigated. The $\mathrm{Ce}-\mathrm{Zr}$-Co mixed oxides were obtained by the pseudo sol-gel like method, based on metallic propionates polymerization and thermal decomposition, whereas the gold-supported Ce-Zr-Co mixed oxides catalysts were prepared using the direct anionic exchange. The catalysts were characterized using XRD, TPR, and EDXS-TEM. The presence of Au in doped Ce-Zr-Co oxide catalyst decreases the temperature necessary to reduce the cobalt and the cerium loaded in the catalyst and favors a different reaction pathway, improving the acetaldehyde route by ethanol dehydrogenation, instead of the ethylene route by ethanol dehydration or methane re-adsorption, thus increasing the catalytic activity and selectivity into hydrogen.
\end{abstract}

Keywords: ethanol steam reforming; hydrogen; gold; cerium-zirconium-cobalt mixed oxides 


\section{Introduction}

Energy is the key element in the interaction between nature and society and is considered as an essential requirement for the economic development [1]. Nowadays, $87 \%$ of the primary energy demand is obtained from non-renewable resources with limited availability as fossil and nuclear sources [2]. In addition, the energy production from traditional sources is considered to be polluting and unsustainable. Carbon dioxide emissions during the energy generation from the fossil fuels have become one of the principal environmental preoccupations in the last few years, since it is considered as a major participant to global warming. In the near future, it is necessary to produce energy using alternative sources, considered as renewable, sustainable, efficient, safe and economically attractive [3]. For this purpose, the use of hydrogen as an efficient and clean fuel is an interesting alternative to the future way to produce energy, but only if obtained from a sustainable source. Hydrogen produced from biofuels such as bioethanol, obtained by biomass fermentation, has a great potential to produce sustainable energy $[4,5]$.

The global reaction of steam reforming of ethanol can be represented by the following general Equation 1:

$$
\mathrm{CH}_{3} \mathrm{CH}_{2} \mathrm{OH}+3 \mathrm{H}_{2} \mathrm{O}=2 \mathrm{CO}_{2}+6 \mathrm{H}_{2}
$$

However, different parallel reaction paths exist, such as dehydration into ethylene, dehydrogenation into acetaldehyde, condensation to acetone and cracking reactions [6-8]. The relative contribution of the different routes depends on the nature of the support, the active phase and the conditions of the process, as can be seen in Scheme 1.

Scheme 1. Possible path route in steam reforming of ethanol.

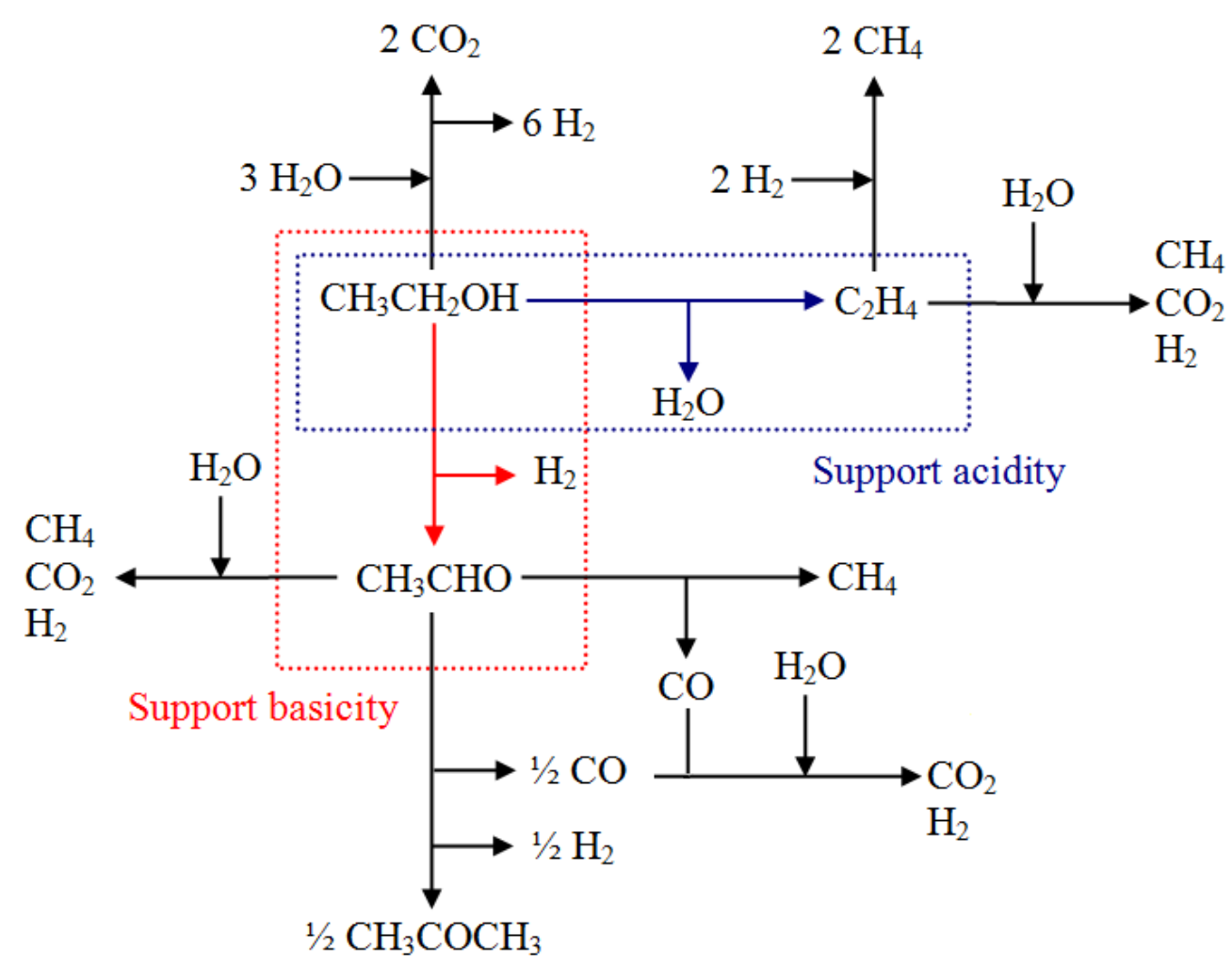


Many active species have been evaluated for the steam reforming of ethanol: noble ( $\mathrm{Rh}, \mathrm{Ru}, \mathrm{Re}, \mathrm{Pd}$, Ir, Pt, Rh-Pt, Rh-Pd, Ru-Pt, ) and transition ( $\mathrm{Ni}, \mathrm{Cu}, \mathrm{Co}$ ) metals supported on metal oxides, with a wide range of acid-base and redox properties, which have been the subject of several reviews in the last years $[4,5,9,10]$. Some catalysts based on copper and nickel revealed interesting activities [11-14] but among the systems reported in the literature, the use of cobalt or rhodium-based catalysts as active phase seems to give the most promising results $[15,16]$. Although bimetallic noble/transition-based catalyst (Rh-Co, Ru-Co, Rh-Ni) studied for this reaction showed interesting results [17,18], supports with oxygen mobility, such as $\mathrm{CeO}_{2}$ and $\mathrm{CeO}_{2}-\mathrm{ZrO}_{2}$, have received special attention since they are expected to act as promoters in improving the catalytic stability and preventing carbonaceous formations $[19,20]$.

The ethanol steam reforming products (catalytic selectivity) are the result of a complicated network of reactions strongly influenced by the active phase oxidation state $[21,22]$, the nature of the support, the activation process, the water/ethanol ratio, the reaction temperature and the contact time between the reactant and the catalyst [5,6]. Furthermore, the reaction conditions induce changes in the catalyst physico-chemical properties (i.e., additional reduction of active phase, solid state reactions, sintering, etc.) and therefore in the catalytic selectivity and stability.

In some earlier publications, it was reported that the insertion of Co, as active phase [23-25] into the Ce-Zr mixed oxides and the subsequent doping with $\mathrm{Rh}$ [26,27], improve the catalytic stability and selectivity for ethanol steam reforming.

In this work, the influence of gold on Ce-Zr-Co mixed oxides, with different $\mathrm{Ce} / \mathrm{Zr}$ ratios, is evaluated in the reaction of steam reforming of ethanol. The phase Ce-Zr-Co on its own is already identified as active for this reaction, but the use of gold could promote the activity and affects the route of production of hydrogen going through the acetaldehyde intermediate [28]. The catalysts were also tested in the reaction of $\mathrm{CO}$ oxidation for which gold is known to be the most active metal when present as nanosized particles [29]. The choice of studying this reaction was made because gold supported on the type of supports as prepared for this work has not yet been explored for this reaction, but also because CO oxidation serves as a probe reaction for both electronic and geometric factors. The oxidation of carbon monoxide by oxygen is a reaction which is described in the literature as being sensitive to the particle size, the support reducibility and the interaction of gold with the support [30].

\section{Experimental}

\subsection{Preparation of the Catalysts}

\subsubsection{Preparation of the Ce-Zr-Co Mixed Oxides}

Two Ce-Zr-Co mixed oxides, $\left(\mathrm{Ce}_{\mathrm{w}} \mathrm{Zr}_{\mathrm{y}} \mathrm{Co}_{0.9} \mathrm{O}_{8-\delta}, \mathrm{w}+\mathrm{y}=3.1\right)$, were synthesized by a pseudo sol-gel method, based on the thermal decomposition of propionate precursors, as reported by Vargas et al. [23]. The starting materials for $\mathrm{Ce}, \mathrm{Zr}$ and $\mathrm{Co}$ were cerium (III) acetate hydrate, zirconium (IV) acetylacetonate and cobalt (II) acetate hydrate, which all led exclusively to propionate precursors in propionic acid. The salts with concentration of $0.12 \mathrm{~mol} \mathrm{~L}^{-1}$ were dissolved in boiling propionic acid, separately. The three boiling solutions were mixed and the solvent was evaporated until a resin was formed. The resin was thermally treated at $500{ }^{\circ} \mathrm{C}$ in air by heating at a rate of $2^{\circ} \mathrm{C} \mathrm{min}^{-1}$ for $6 \mathrm{~h}$. 


\subsubsection{Preparation of the $\mathrm{Au} / \mathrm{Ce}-\mathrm{Zr}-\mathrm{Co}$ Samples}

The gold was subsequently deposited on the mixed oxide by a direct anionic exchange (DAE) between the support and a $10^{-4} \mathrm{M}$ solution of $\mathrm{HAuCL}_{4}$ in order to deposit $1 \mathrm{wt} . \%$ of the gold. The chlorine was completely removed by an ammonia washing ( $4 \mathrm{M}$ solution, $1 \mathrm{~h}$ ) and a subsequent water washing, which both improves the activity and prevents sintering, as reported by Ivanova et al. [31]. The catalysts were calcined in air at $300{ }^{\circ} \mathrm{C}$ for $4 \mathrm{~h}$ with a ramp rate of $5^{\circ} \mathrm{C} \mathrm{min}^{-1}$.

\subsection{Characterizations}

The chemical analysis of $\mathrm{Au}$ and $\mathrm{Cl}$ was performed by inductively coupled plasma atom emission spectroscopy ICPS at the CNRS Centre of Chemical Analysis (Vernaison, France). The detection limit was $150 \mathrm{ppm}$ for $\mathrm{Cl}$. The analyses were carried out following the calcination of the catalyst. The $\mathrm{Au}$ weight loading is expressed as the percentage of Au per weight of calcined catalyst.

Previous to the gold deposition, the micro-homogeneity of the Ce-Zr-Co samples was determined by EDXS micro-analysis on a TOPCON EM-002B apparatus (acceleration voltage $200 \mathrm{kV}$ ).

The crystallinity of the Ce-Zr-Co mixed oxide was studied by X-ray diffraction (Siemens D5000, $\mathrm{Cu} \mathrm{K} \alpha$ radiation, $20^{\circ}<2 \theta<65^{\circ}, 0.068 \mathrm{~min}^{-1}$ ).

The reducibility was studied by Thermo-Programmed Reduction (TPR). Measurements were carried out with a home-made apparatus equipped with a TCD on $50 \mathrm{mg}$ of sample heated from room temperature to $900{ }^{\circ} \mathrm{C}$ at $15{ }^{\circ} \mathrm{C} \mathrm{min}^{-1}$ under $3.85 \% \mathrm{H}_{2} / \mathrm{Ar}$ mixture $\left(50 \mathrm{~mL} \mathrm{~min}^{-1}\right)$.

\subsection{Catalytic Tests}

\subsubsection{CO Oxidation}

The reaction was performed at atmospheric pressure using a fixed bed quartz packed micro-reactor with $50 \mathrm{mg}$ catalyst diluted in cordierite and a gas mixture of $1.5 \% \mathrm{CO}$ and $5 \% \mathrm{O}_{2}$ in $\mathrm{He}$ with a total flow rate of $50 \mathrm{~mL} \mathrm{m^{-1 }}$ (GHSV 23,000 h $\mathrm{h}^{-1}$ ). The flows were regulated using Tylan mass flow controllers. The catalytic reaction was performed from room temperature to $300{ }^{\circ} \mathrm{C}$ with a heating rate of $5{ }^{\circ} \mathrm{C} \mathrm{min}^{-1}$, with temperature monitored and controlled by a Eurotherm system. Analysis for both $\mathrm{CO}$ and $\mathrm{CO}_{2}$ were performed by Rosemount Infrared analyzers. The experiment was repeated several times in order to measure the reproducibility. Before each test, the catalyst was pre-treated at $300{ }^{\circ} \mathrm{C}$ in air for $2 \mathrm{~h}$.

\subsubsection{Ethanol Steam Reforming}

The ethanol steam reforming reaction was carried out in a fixed bed reactor, at atmospheric pressure, using $160 \mathrm{mg}$ of catalyst, heated at $2{ }^{\circ} \mathrm{C} \mathrm{min}{ }^{-1}$ from room temperature to $440{ }^{\circ} \mathrm{C}$ in an $\mathrm{Ar} / \mathrm{N}_{2}$ mixture (total flow: $35 \mathrm{~mL} \mathrm{~min}^{-1}, 4: 1 \mathrm{M}$, GHSV $5,000 \mathrm{~h}^{-1}$ ), without any reduction treatment. After $1 \mathrm{~h}$ at $440{ }^{\circ} \mathrm{C}$, the ethanol/water mixture $\left(15 \mathrm{~mL} \mathrm{~min}^{-1}\right.$ of mixture in gas phase) was introduced using the same $\mathrm{Ar} / \mathrm{N}_{2}$ mixture (GHSV: $26,000 \mathrm{~h}^{-1}$ ) as carrier and the reactive test was carried out at $440{ }^{\circ} \mathrm{C}$ for $5 \mathrm{~h}$. The mixture ethanol:water (1:6 molar) in phase liquid was fed by using a Gilson HPLC pump 
to a evaporator before the reactor inlet, mixed with the inert gas mixture and introduced into the reactor.

The gas products were analyzed on-line by micro-gas chromatography to identify the principal products and by-products (column Poraplot Q; column molecular sieve $5 \AA$ ) by direct injection of the effluent reactor stream. No condensation of condensable products was performed.

The results are expressed in terms of molar selectivity in the gas phase for $\mathrm{H}_{2}, \mathrm{CO}_{2}, \mathrm{CO}, \mathrm{CH}_{3} \mathrm{CHO}$, $\mathrm{C}_{2} \mathrm{H}_{4}, \mathrm{CH}_{4}$ and $\mathrm{CH}_{3} \mathrm{COCH}_{3}$. When considering only the steam reforming reaction, a maximum of $75 \%$ of hydrogen selectivity can then be achieved with those reaction conditions.

The hydrogen yield is expressed in gram of hydrogen per hour per gram of catalyst, the maximum $\mathrm{H}_{2}$ yield which can be obtained in the reaction conditions is $0.45 \mathrm{~g} \mathrm{H}_{2} \mathrm{~h}^{-1} \mathrm{~g}_{\text {cat }}{ }^{-1}$.

\section{Results and Discussion}

Two samples of Ce-Zr-Co mixed oxides were prepared, $\mathrm{Ce}_{1.85} \mathrm{Zr}_{1.25} \mathrm{Co}_{0.9} \mathrm{O}_{7.4}$ and $\mathrm{Ce}_{1.23} \mathrm{Zr}_{1.87} \mathrm{Co}_{0.9} \mathrm{O}_{7.4}$, and used as supports for gold containing catalysts. The sample with the highest cerium content will be referred to as $\mathrm{CeZrCo}-\mathrm{A}$ whereas the catalyst with the highest $\mathrm{Zr}$ content will be referred to as $\mathrm{CeZrCo}-\mathrm{B}$. The corresponding gold samples will then be designed as $\mathrm{Au} / \mathrm{CeZrCo}-\mathrm{A}$ and $\mathrm{Au} / \mathrm{CeZrCo}-\mathrm{B}$.

The metallic elemental composition for the samples, obtained from ICPS and global EDXS analysis $(200 \mathrm{~nm})$, was found to be very close to the expected theoretical value and showed a high degree of homogeneity. The gold loading (ICPS) was close to the theoretical value of $1 \mathrm{wt} \%$ and almost reproduced in the system with higher cerium content $(0.96 \mathrm{wt} \%)$. This has been already observed for the bare oxide systems [32]. As an example, for catalyst $\mathrm{B}$, the theoretical molar distribution is $\mathrm{Ce}$ $30.8 \%$, Zr 46.7\%, Co 22.5\%. ICP analysis gave Ce 33.2\%, Zr 44.8\%, Co $22.0 \%$ and the composition from EDX analysis was Ce $33.0 \%$, $\mathrm{Zr} 44.7 \%$, Co $22.3 \%$. The $\mathrm{Cl}$ content is under the detection limit $(150 \mathrm{ppm})$ which allows claiming that the catalyst is almost chlorine free. However, from the local composition measurements (14.4 nm), EDXS analysis, some non-homogeneous composition zones are observed. Nevertheless, the sample with higher $\mathrm{Ce} / \mathrm{Zr}$ ratio in the mixed oxides exhibits the best global and local chemical homogeneity.

The diffractograms of the CeZrCo mixed oxides, before and after the gold deposition are presented in Figure 1.

The mixed oxides preparation method of bare Ce-Zr-Co mixed oxides allows the crystallization without any noticeable phase rejection, showing the main cubic structure of $\mathrm{Ce}-\mathrm{Zr}$ fluorite type oxide. No single cerium or zirconium oxides are detected $\left(\mathrm{CeO}_{2}, \mathrm{ZrO}_{2}\right)$ and only a small weak peak corresponding to cobalt oxide spinel phase is present in the samples at $36^{\circ}$ (Figure $1 \mathrm{a}, \mathrm{b}$ ). Depending upon $\mathrm{Ce} / \mathrm{Zr}$ ratio, it can be noted a shift of the diffraction peak to lower angles $(2 \theta)$ for the sample with high $\mathrm{Ce} / \mathrm{Zr}$ ratio, which could be attributed to the zirconium and cobalt insertion, both having smaller ionic radii compared to cerium ionic radius. The formation of mixed propionates during the polymerization step of the preparation allows the formation of the Co-O-Zr and Co-O-Ce bonds as well as $\mathrm{Zr}-\mathrm{O}-\mathrm{Ce}$ bonds which ensures the insertion of cobalt in the mixed oxide lattice.

After the gold deposition on the mixed Ce-Zr-Co oxide surface, an additional diffraction line is visible at $2 \theta=38.4^{\circ}$, corresponding to the $\mathrm{Au}(111)$ (Figure $1 \mathrm{c}, \mathrm{d}$ ), without obvious changes in the main 
peaks corresponding to the fluorite structure. However, it is possible to observe a shift in the main diffraction lines of the fluorite structure, indicating a modification in the degree of cobalt insertion in the host structure, and resulting in different intensities in the cobalt oxide and gold peaks diffraction. For the lower cerium content samples (Figure 1b,d), lower diffraction angles are observed after the gold deposition. This behavior is a consequence of the different degree of vacancies initially present in the $\mathrm{CeZrCo}$ mixed oxide fluorite structure as compared with those generated in the presence of gold. A similar behavior was noted in gold/ceria catalysts [33,34].

Figure 1. X-Ray Diffractograms of: (a) CeZrCo-A; (b) CeZrCo-B; (c) Au/CeZrCo-A; (d) $\mathrm{Au} / \mathrm{CeZrCo}-\mathrm{B}$.

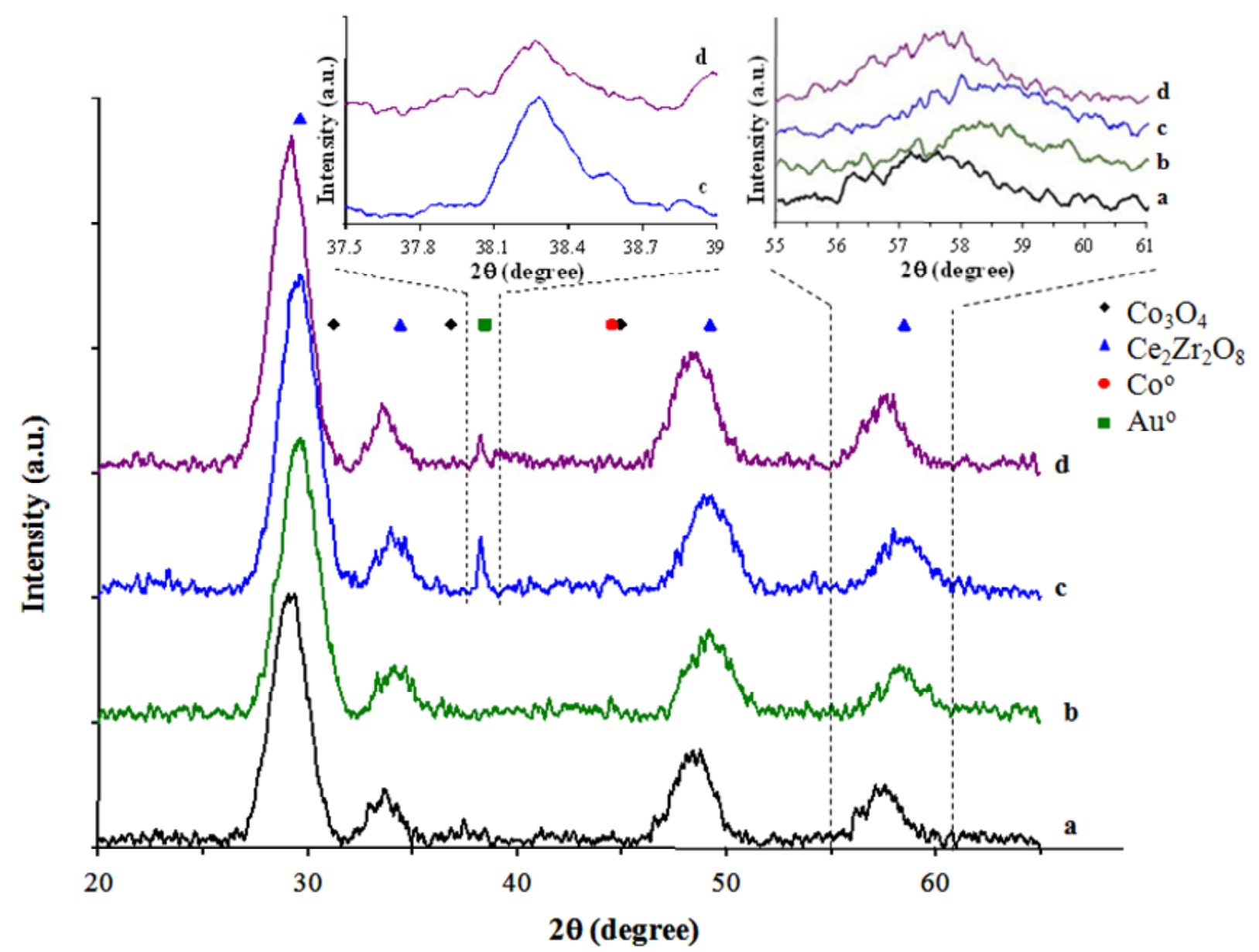

From the X-ray diffractograms, it is possible to calculate the particle size of gold by means of Debye-Scherrer equation [35]. With the increase of zirconium content, the particles size decreases from $28 \mathrm{~nm}$ for $\mathrm{Au} / \mathrm{CeZrCo}-\mathrm{A}$ to $24 \mathrm{~nm}$ for $\mathrm{Au} / \mathrm{CeZrCo}-\mathrm{B}$, which could be attributed to a different grafting mode of the gold precursor on the bare supports [30,32,36]. In any case, estimation of the size by means of Debye-Scherrer equation tends to lead to an overestimation of the size as only large particles undergo diffraction. Unfortunately, it was not possible to achieve a more accurate particle size distribution because of the poor contrast obtained by transmission electron microscopy.

As the CeZrCo mixed oxide system was prepared to serve as a precursor of small cobalt particles, which is the active phase in the reforming reaction [23,26], a special care of the reducibility of the samples has to be taken. From the reduction profile TPR analysis (Figure 2), it is possible to describe 
and discuss the effect of gold. The influence of gold on the TPR profiles is clear, as both the required temperatures to obtain the reduction of the samples and the way that reduction occurs are markedly affected.

Figure 2. Thermo-programmed reduction (TPR) profiles of samples: (a) CeZrCo-A; (b) $\mathrm{CeZrCo}-\mathrm{B}$; (c) Au/CeZrCo-A; (d) Au/CeZrCo-B.
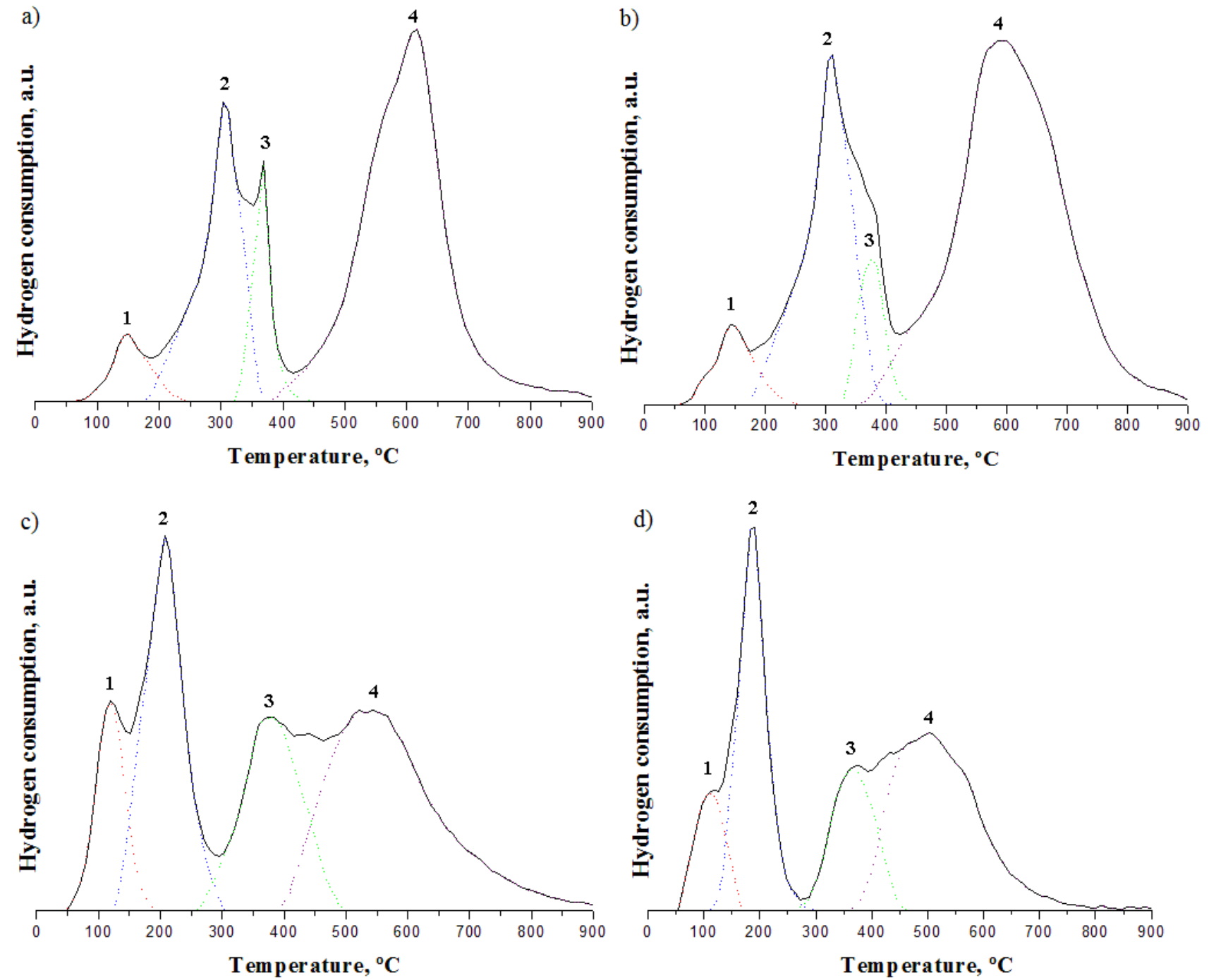

All the samples, independently of the $\mathrm{Ce} / \mathrm{Zr}$ ratio or the presence of $\mathrm{Au}$, led to two zones of reduction (Figure 2). For $\mathrm{Au}$ free samples (Figure 2a,b), the first reduction zone is located below $425{ }^{\circ} \mathrm{C}$, whereas it occurs below $300^{\circ} \mathrm{C}$ for the Au-loaded samples (Figure 2c,d). The first reduction zone is ascribed to the partial reduction of the surface cerium from $\mathrm{Ce}^{4+}$ to $\mathrm{Ce}^{3+}$ along with the simultaneous reduction of the cobalt species from $\mathrm{Co}^{3+}$ and $\mathrm{Co}^{2+}$ to $\mathrm{Co}^{0}$. The second reduction zone at high temperature corresponds to the reduction of the $\mathrm{Co}^{2+}$ incorporated into the fluorite structure and to the reduction of bulk ceria $[25,37]$.

The TPR thermograms were decomposed into four peaks. For Ce-Zr-Co mixed oxides there are three peaks in the reduction zone $\mathrm{I}$, at 150,300 , and $380{ }^{\circ} \mathrm{C}$ and a broad peak in the reduction zone II, between 400 and $900{ }^{\circ} \mathrm{C}$. The complete description of the thermograms has been published elsewhere for slightly different samples. Briefly, for the gold containing Ce-Zr-Co samples, two peaks at 125 and 
$200{ }^{\circ} \mathrm{C}$ are located in the first reduction zone and the second zone of temperature could also be decomposed into two peaks located at $380{ }^{\circ} \mathrm{C}$ and a broad peak between 400 and $900{ }^{\circ} \mathrm{C}$, respectively.

The small consumption of hydrogen centered at around $150{ }^{\circ} \mathrm{C}$ (Figure $2 \mathrm{a}, \mathrm{b}$ ) is attributed to the reduction of highly dispersed cobalt oxide which is not incorporated into the fluorite structure. For the gold-loaded samples, there are both changes in the amount of $\mathrm{H}_{2}$ which is slightly higher and a shift of reduction temperature towards a lower value. These two phenomena confirm the fact that there are indeed small modifications in the crystalline structure, as proven by XRD. The amount of cobalt oxide not incorporated in the fluorite structure increases, i.e., small particles of cobalt oxides are present on the support and their reduction is activated by the gold metallic particle.

By numerical integration, it is possible to calculate the contribution of each species to the overall consumption of hydrogen and to estimate the respective proportions of hydrogen allocated to zone 1 and 2. By assuming that, in the fresh samples, gold is in a metallic state-gold usually undergoes autoreduction upon calcination and the presence of metallic gold is proven by XRD — and that cobalt oxide, which is initially present as a stable oxide in the form of $\left(\mathrm{CoO} \cdot \mathrm{Co}_{2} \mathrm{O}_{3}\right)$ is completely reduced upon hydrogen exposure, it is possible to determine the percentage of $\mathrm{Ce}^{4+}$ reduced to $\mathrm{Ce}^{3+}$ during the TPR. The overall hydrogen consumption per gram of catalyst, the percentage of partial reduction (in zone 1) and the percentage of hydrogen consumed by each species are presented in Table 1.

Table 1. Total hydrogen consumptions, peak area distribution of samples and percentage of cerium reduced after TPR.

\begin{tabular}{cccccccc}
\hline Samples & $\begin{array}{c}\text { Peak 1 } \\
(\%)\end{array}$ & $\begin{array}{c}\text { Peak 2 } \\
(\mathbf{\%})\end{array}$ & $\begin{array}{c}\text { Peak 3 } \\
(\mathbf{\%})\end{array}$ & $\begin{array}{c}\text { Peak 4 } \\
(\mathbf{\%})\end{array}$ & $\begin{array}{c}\text { Zone I } \\
(\mathbf{\%})\end{array}$ & $\begin{array}{c}\mathbf{H}_{\mathbf{2}} \\
\left(\mathbf{m L}_{\mathbf{S T P}} \mathbf{g}^{-\mathbf{1}}\right)\end{array}$ & $\begin{array}{c}\mathbf{C e}^{\text {IV }} \rightarrow \mathbf{C e}^{\text {III }} \\
(\mathbf{\%})\end{array}$ \\
\hline $\mathrm{CeZrCo}-\mathrm{A}$ & 5 & 24 & 9 & 61 & 39 & 68 & 47 \\
$\mathrm{Au} / \mathrm{CeZrCo}-\mathrm{A}$ & 11 & 27 & 21 & 41 & 38 & 76 & 70 \\
$\mathrm{CeZrCo}-\mathrm{B}$ & 5 & 25 & 6 & 63 & 37 & 68 & 56 \\
$\mathrm{Au} / \mathrm{CeZrCo}-\mathrm{B}$ & 10 & 30 & 17 & 43 & 40 & 58 & 26 \\
\hline
\end{tabular}

For the Au-free samples, the hydrogen consumption from the first three peaks of reduction is quasi identical $\left(1.2 \times 10^{-3} \mathrm{~mol} \mathrm{~g}^{-1} \mathrm{H}_{2}\right.$ for CeZrCo-A and $1.1 \times 10^{-3}$ for CeZrCo-B). The difference between these values and the calculated hydrogen consumption needed for complete cobalt species reduction could directly provide the percentage of the surface ceria reduction. For both samples, 39 and $37 \%$ of ceria surface reduction is obtained, respectively. In addition, the unaltered $\mathrm{H}_{2}$ consumption for the peak 4 indicates a constant quantity of reduced bulk $\mathrm{Ce}^{+4}$, no matter the $\mathrm{Zr}$ composition. The presence of $\mathrm{Zr}$ does not seem to alter the reduction of the bulk cerium content.

However, the reduction of cobalt and cerium changes in the presence of gold being promoted by its presence; the first three peaks of cobalt reduction are completely repositioned. For the first peak, the temperature for reduction is lower, but the volume of consumed hydrogen is doubled, indicating the higher content of cobalt species rejected from the fluorite structure after gold deposition. Moreover, the presence of gold facilitates the $\mathrm{Co}^{3+}$ to $\mathrm{Co}^{2+}$ reduction (peak 2) for which a decrease of the temperature of reduction by $100{ }^{\circ} \mathrm{C}$ is observed. The amount of hydrogen consumed in this region is similar for all samples, which confirms that only cobalt is involved in this process. The presence of gold not only induces small structural changes as proven by XRD but modifies the reducibility of the 
two species corresponding to the low temperature peaks. There is a higher reduction degrees at low temperature observed for both catalysts in the presence of gold. This confirms lower bonding energies of the oxygen on the surface oxidized species and therefore a higher mobility and higher reducibility, which generate vacancies on the surface or species with lower oxidation state which act as active sites (in this case reducing cobalt).

The third peak of reduction seems a little bit more complicated to explain. If the consumption is caused only by $\mathrm{Co}$ (II) to $\mathrm{Co}(0)$ reduction, the consumption of hydrogen should not change. But an increase in the hydrogen consumption is observed and the temperature of reduction remains unchanged, indicating a higher contribution of the surface ceria reduction. This is confirmed by the fact that for the CeZrCo-B system, where the quantity of $\mathrm{Ce}$ is lower, the hydrogen consumption is also lower. However, the calculations of the surface ceria contribution to the reduction process show very similar values, $38 \%$ for $\mathrm{Au}-\mathrm{CeZrCo}-\mathrm{A}$ and $40 \%$ for $\mathrm{Au}-\mathrm{CeZrCo}-\mathrm{B}$. The later indicates that the gold presence provokes cobalt rejection of the fluorite structure resulting in a higher $\mathrm{H}_{2}$ consumption at low temperature compensated by a higher surface ceria reduction contribution.

The high temperature peak of reduction $\left(>500{ }^{\circ} \mathrm{C}\right)$ corresponding to the bulk cerium reduction shows a decrease in terms of hydrogen consumption when gold is present which can be directly related to the increase of the surface ceria reduction (Table 1).

Regardless of the composition of the catalyst, there exists a temperature range free of reduction for all the samples, which allows the possibility to clearly distinguish the zone of partial reduction. This allows the use of catalytic systems in which cobalt is partially reduced and is chemically stable at the temperature at which the reaction of ethanol reforming occurs.

For CeZrCo samples, the zone $\mathrm{I}$ is the count of peaks 1, 2, and 3. Otherwise, the zone $\mathrm{I}$ in $\mathrm{Au} / \mathrm{CeZrCo}$ samples is the count of peaks 1 and 2. By comparing the percentage of reduction of zone I and II of gold containing and not containing samples, it is possible to observe a similar area distribution, in which the hydrogen consumption is near to $40 \%$ of the total one.

\subsection{CO Oxidation}

The complete oxidation of carbon monoxide is one of the most studied reactions for gold-containing catalysts since the astonishing discovery of Haruta et al. [29] that very small gold nanoparticles exhibit catalytic activity at sub-ambient temperature. The method of preparation has a great influence on the catalytic behavior since it affects the gold particles' size, morphology and oxidation state. Furthermore, gold catalysts activity is influenced by several parameters such as acidity or basicity of the support, the thermal treatment or the nature of activation process [30]. Therefore the $\mathrm{CO}$ reaction serves as a probe reaction not only for the particle size but also to reveal subtle changes in the electronic state of gold or in the morphology of the particles, modifications which other techniques are at pains to reveal. The conversion of carbon monoxide as a function of the temperature is presented in Figure 3 for all the samples with or without gold. 
Figure 3. Conversion de $\mathrm{CO}$ as a function of temperature.

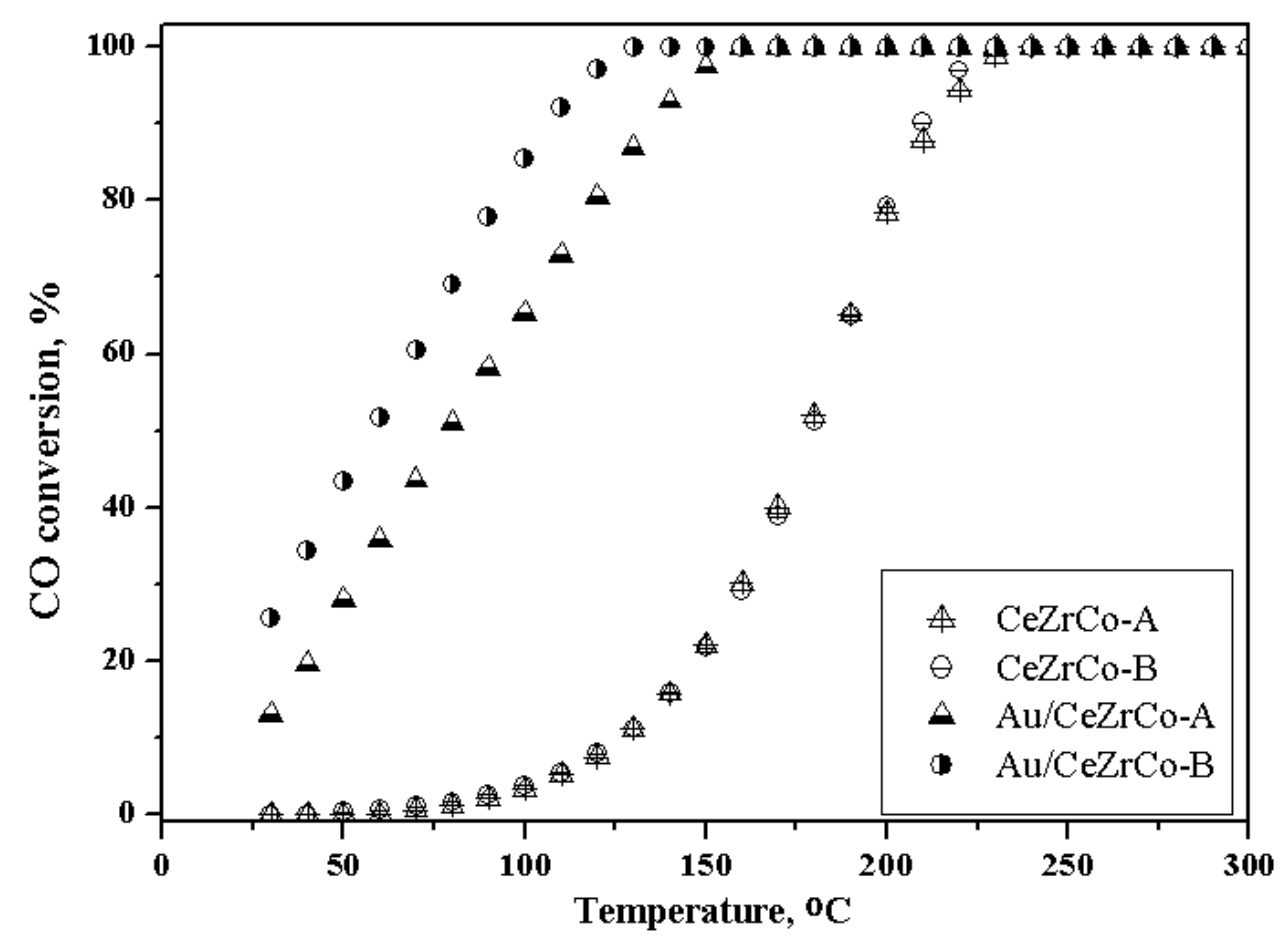

The Ce/Zr ratio does not influence the activity of the gold free samples. The complete CO oxidation is obtained at $225^{\circ} \mathrm{C}$. When gold is deposited on the mixed oxides phase the behavior of the catalysts changes significantly. They become very active, showing even an activity at room temperature and with a total conversion at $c a .125{ }^{\circ} \mathrm{C}$. The $\mathrm{Au} / \mathrm{CeZrCo}-\mathrm{B}$ sample is slightly more active than $\mathrm{Au} / \mathrm{CeZrCo}-\mathrm{A}$ sample, which could be attributed to the difference in the gold particle size observed for these samples.

\subsection{Ethanol Steam Reforming}

In order to elucidate the influence of gold on the Ce-Zr-Co catalytic behavior, the reaction of ethanol steam reforming was carried out at low temperature $\left(440{ }^{\circ} \mathrm{C}\right)$. This temperature favors the production of acetone, by acetaldehyde condensation, and the deactivation by carbonaceous species is impeded. For the same reasons, the catalysts were not reduced before the catalytic test, and were therefore used as prepared [25]. The gas phase distribution-i.e., the selectivity-is strongly influenced by the reaction temperature and the active phase reduction state (metallic phase). At temperatures higher than $550{ }^{\circ} \mathrm{C}$, only the main products $\left(\mathrm{H}_{2}, \mathrm{CO}, \mathrm{CO}_{2}, \mathrm{CH}_{4}\right)$ are formed, as a consequence of the transformation of the intermediate adsorbed compounds [8,25] and of some thermodynamics restrictions. A similar behavior is observed when the active phase is in the metallic state, which is so influential that it hides the role of promoters occurring only in the deactivation route and affects long-term stability. The presence of trace of propylene can be attributed to acetone hydrogenation [38].

The evolution of the catalytic conversion of the samples with the reaction time is given in Figure 4. 
Figure 4. Ethanol conversion as a function of time on stream.

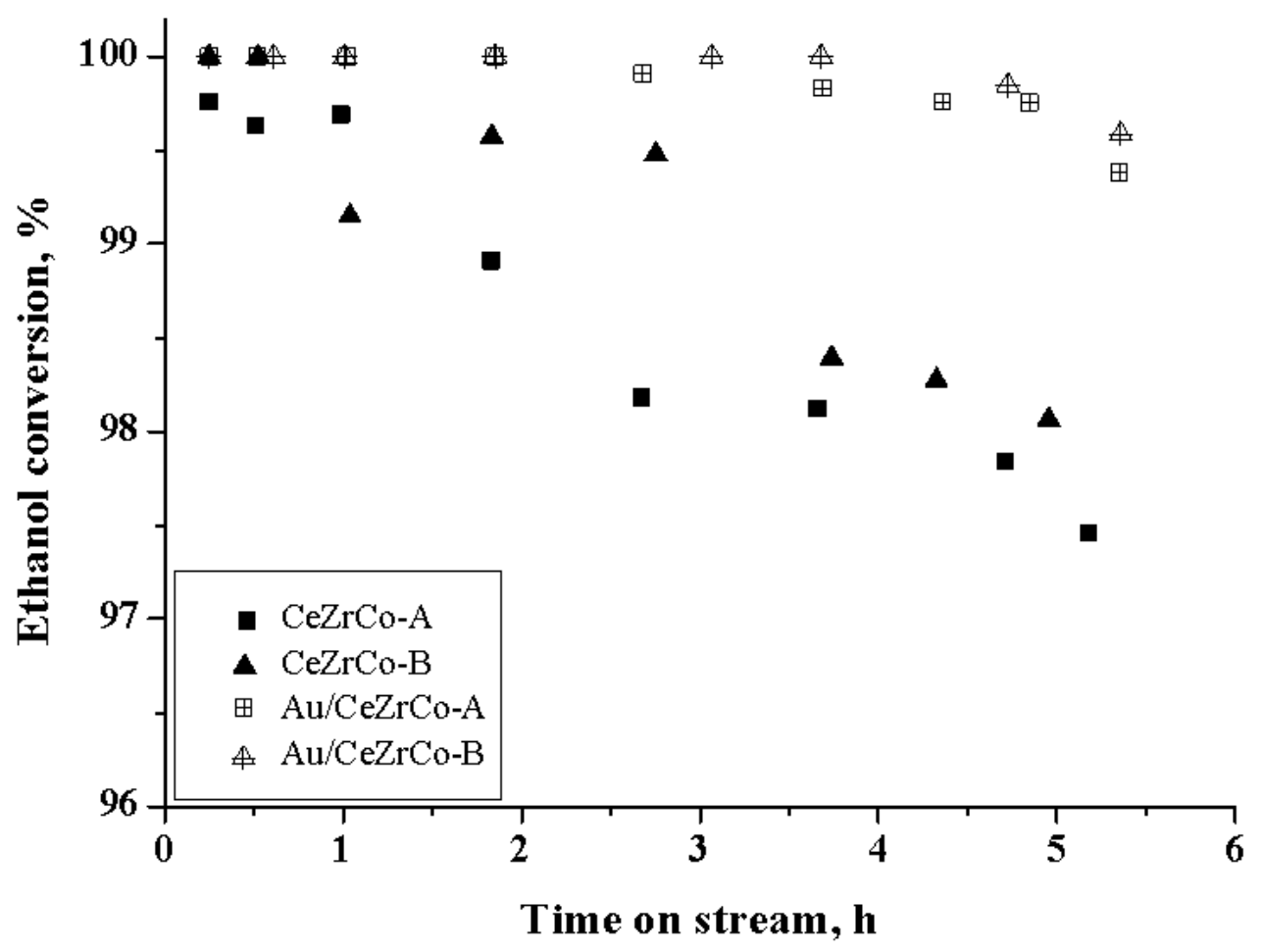

All the catalytic systems are very active for the reaction with an ethanol conversion close to $100 \%$ in the first hours of the reaction, despite the fact that no reducing treatment was performed. The change in the $\mathrm{Ce} / \mathrm{Zr}$ ratio does not seem to have a great influence on the ethanol conversion but has an effect in the catalytic selectivity, modifying the acetone and ethylene production. In the case of $\mathrm{Ce}-\mathrm{Zr}-\mathrm{Co}$ samples, the activity decreases slowly down to $98 \%$ after $5 \mathrm{~h}$ of reaction whereas for the $\mathrm{Au} / \mathrm{CeZrCo}$ samples, the activity remains higher than $99.8 \%$ for the first $5 \mathrm{~h}$ of reaction. The gold addition seems to change the kinetics of deactivation and to stabilize the conversion for a longer time probably due to a higher activity to transform the adsorbed intermediates or by changing the reaction route. The process of carbonaceous deposition and/or active surface change by the adsorption of intermediary products, as principal causes of deactivation [39] seems to be inhibited or delayed.

In Figure 5, the gas phase distribution for both gold containing catalysts compared with the bare Ce-Zr-Co catalysts. In the Figure 5a, $\mathrm{a}^{\prime}$ the molar product distribution of the main products $\left(\mathrm{H}_{2}, \mathrm{CO}_{2}\right.$ and $\mathrm{CO}$ ) is presented, whereas in Figure $5 \mathrm{~b}, \mathrm{~b}^{\prime}$ the molar distribution of the secondary products $\left(\mathrm{CH}_{4}, \mathrm{C}_{2} \mathrm{H}_{4}, \mathrm{CH}_{3} \mathrm{COCH}_{3}\right)$ are given, which gives some insights into the reaction path. 
Figure 5. Gas phase distribution as a function of time on stream: (a,a') CeZrCo-A catalysts; $\left(\mathbf{b}, \mathbf{b}^{\prime}\right) \mathrm{CeZrCo-B}$ catalysts. Full symbols-CeZrCo samples, empty symbols- $-\mathrm{Au} / \mathrm{CeZrCo}$ samples.
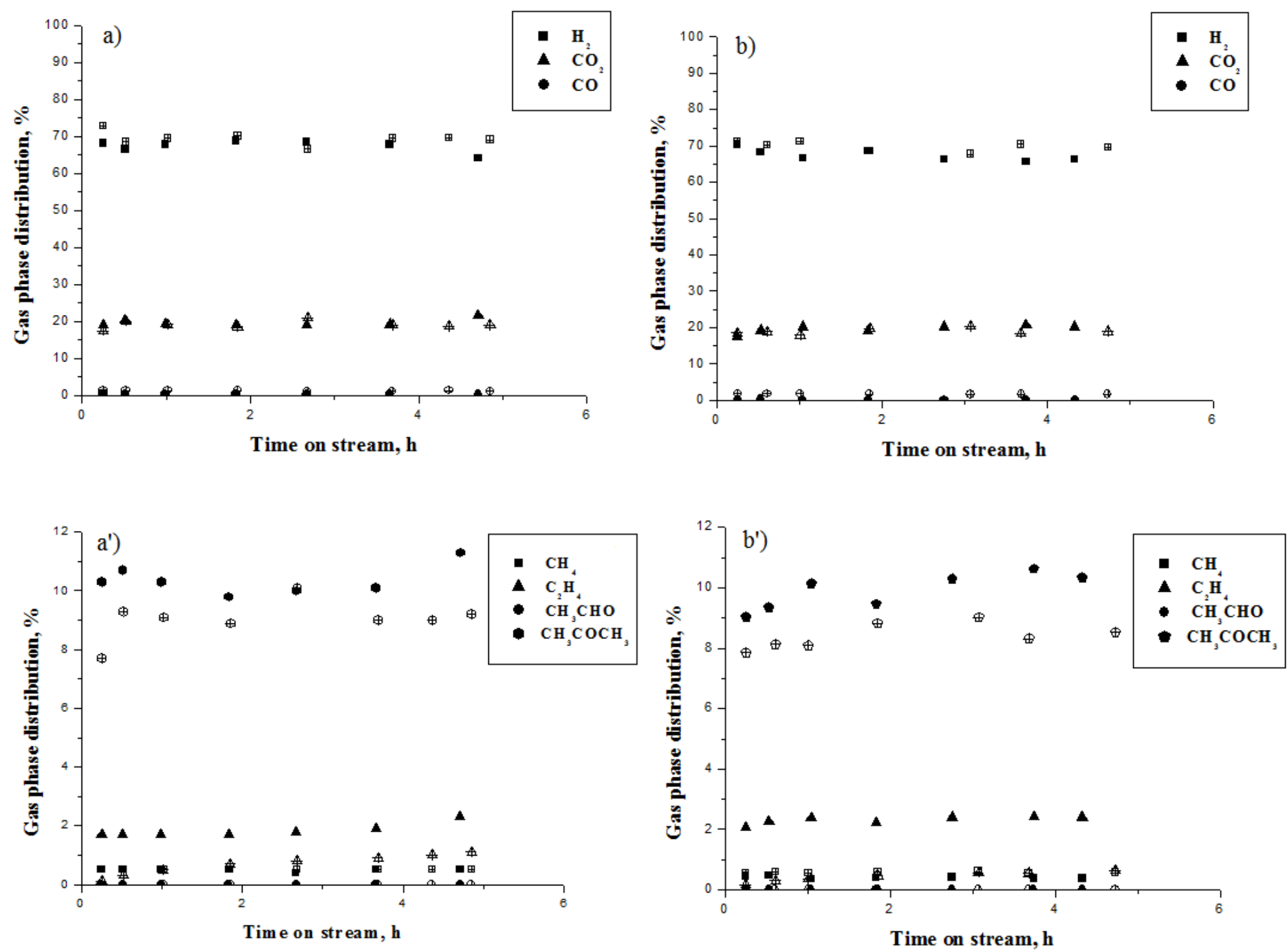
The Table 2 is summarizing the average molar distribution of products during the whole time of reaction.

Table 2. Average distribution (in $\%$ mol ) in the gas phase on CeZrCo and $\mathrm{Au} / \mathrm{CeZrCo}$ samples.

\begin{tabular}{cccccccc}
\hline Sample & $\mathbf{C H}_{4}$ & $\mathbf{C O}_{\mathbf{2}}$ & $\mathbf{C}_{\mathbf{2}} \mathbf{H}_{\mathbf{4}}$ & $\mathbf{H}_{\mathbf{2}}$ & $\mathbf{C O}$ & $\mathbf{C}_{\mathbf{3}} \mathbf{H}_{\mathbf{6}}$ & $\mathbf{C H}_{\mathbf{3}} \mathbf{C O C H}_{\mathbf{3}}$ \\
\hline $\mathrm{CeZrCo}-\mathrm{A}$ & 0.5 & 19.6 & 1.8 & 67.4 & 0.3 & 0.1 & 10.4 \\
$\mathrm{Au} / \mathrm{CeZrCo}-\mathrm{A}$ & 0.5 & 19.0 & 0.7 & 69.4 & 1.2 & 0.1 & 9.1 \\
$\mathrm{CeZrCo}-\mathrm{B}$ & 0.4 & 19.6 & 2.3 & 67.4 & 0.2 & 0.1 & 9.9 \\
$\mathrm{Au} / \mathrm{CeZrCo}-\mathrm{B}$ & 0.6 & 19.0 & 0.5 & 69.7 & 1.7 & 0.1 & 8.4 \\
\hline
\end{tabular}

For $\mathrm{CeZrCo}$ and $\mathrm{Au} / \mathrm{CeZrCo}$ samples, independently of $\mathrm{Ce} / \mathrm{Zr}$ ratio, the molar distribution of the main products in the gas phase remains almost stable with time on stream, independently of the conversion.

However, in the presence of gold, the gas phase distribution of $\mathrm{H}_{2}$ and minor products, with the exception of methane, presents some significant changes resulting from a different reaction pathway, which favors the activation of ethanol through $\mathrm{CH}_{3} \mathrm{CHO}$ instead of the one through $\mathrm{C}_{2} \mathrm{H}_{4}$. The significant decrease of ethylene in the presence of gold tends to show that the dehydration of ethanol (acid way) decreased. Consequently the second activation way by dehydrogenation into acetaldehyde is favored.

In the presence of $\mathrm{Au}$, a high selectivity toward hydrogen is observed, along with a higher $\mathrm{CO}$ production. A decrease of both of acetone and ethylene is obtained, but in the case of this latter product, it is more marked. The $\mathrm{CH}_{4}$ and $\mathrm{CO}_{2}$ production remains almost constant despite the addition of gold. This behavior suggests that in the presence of gold, the ethanol-reforming reaction proceeds mainly on $\mathrm{CeZrCo}$ actives sites preferentially through the acetaldehyde intermediate. The preferential decomposition of this intermediate by decarboxylation produces $\mathrm{CO}$ and $\mathrm{CH}_{4}$, or its corresponding adsorbed species. Therefore, acetone production is affected since it is formed by acetaldehyde condensation reaction.

The adsorbed species are rapidly evolved in the steam reforming reaction increasing the $\mathrm{CO}$ and $\mathrm{H}_{2}$ amounts (Scheme 1). The major $\mathrm{CO}$ interaction in the presence of gold could be confirmed by the catalytic results as shown in the total oxidation of $\mathrm{CO}$. Otherwise, the slight increase in $\mathrm{CO}_{2}$ amounts in gold containing samples could be explained through the water gas shift reaction (WGSR). It is also interesting to note the absence of acetaldehyde formation during the course of the reaction, despite the slight decrease in the conversion, thus confirming the high rate of conversion of acetaldehyde to other products.

Another interesting result concerns the increase in the amount of ethylene produced at a higher $\mathrm{Ce} / \mathrm{Zr}$ ratio, which is attributed to the inclusion of $\mathrm{Zr}$ in the structure, decreasing the acidity of the support and therefore favoring the reaction pathway to the acetone production. The effect of $\mathrm{Ce} / \mathrm{Zr}$ molar ratio on redox behavior and of the acid-base properties acid-base is well known. A catalyst with acidic properties favors the dehydration route to produce ethylene and water whereas catalysts with basic properties favor the dehydrogenation route producing acetaldehyde and hydrogen. At low temperatures of reaction, acetaldehyde is converted by ketonization reactions to acetone. 
When the hydrogen yield is calculated (Figure 6), a higher hydrogen production, by gram of catalyst and per hour is obtained for the gold containing catalysts.

Figure 6. Hydrogen yield as a function of time on stream. (Full symbols: CeZrCo samples, empty symbols: Au/CeZrCo samples).

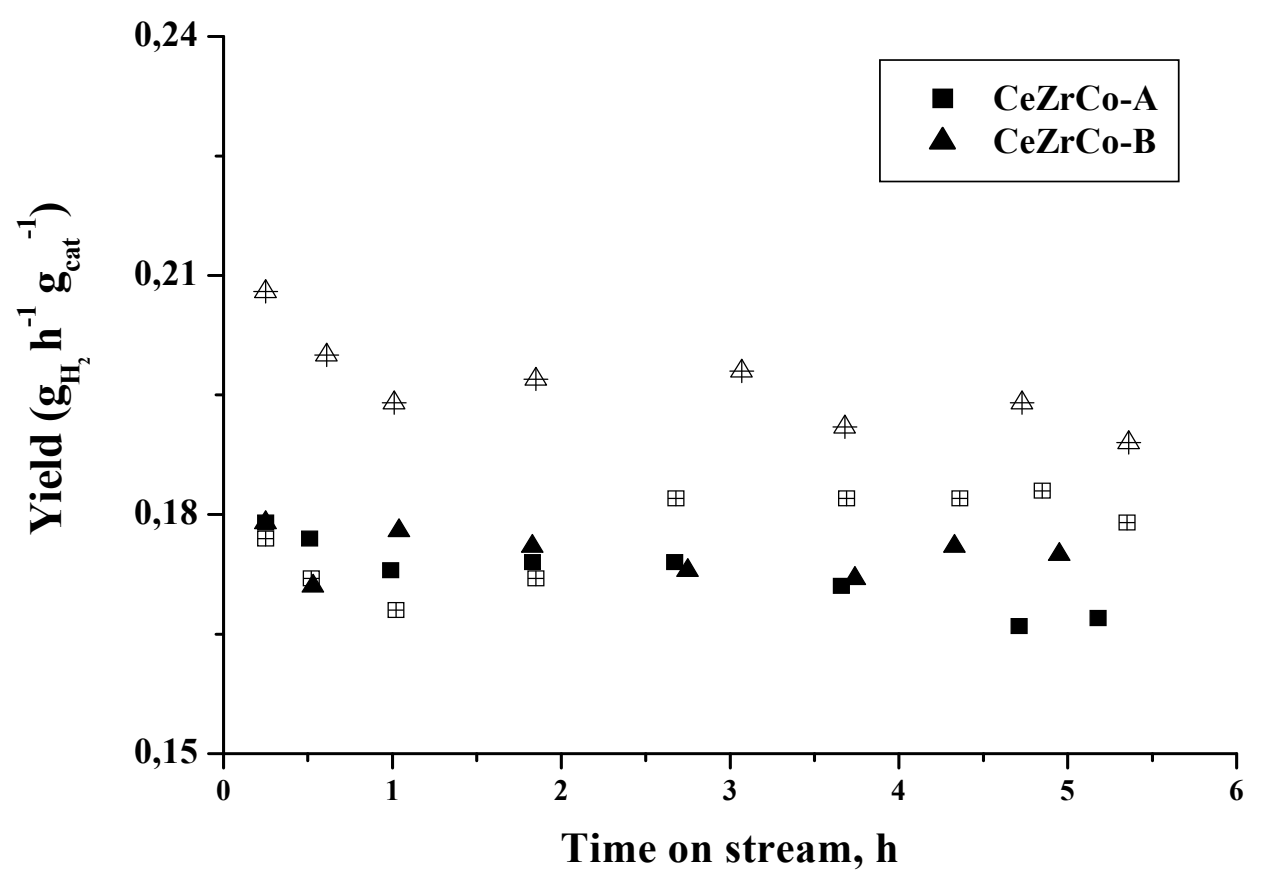

The differences in the hydrogen yield obtained in $\mathrm{CeZrCo}$ and $\mathrm{Au} / \mathrm{CeZrCo}$ catalyst, are influenced by the decrease of the conversion but not by the hydrogen selectivity changes and as a consequence, the hydrogen yield is higher in the gold containing samples.

In Figure 7 the diffractograms of the $\mathrm{CeZrCo}$ and $\mathrm{Au} / \mathrm{CeZrCo}$ catalyst, before and after steam reforming reaction are presented.

The samples were evaluated as catalyst without any reduction process, in order to study the gold influence in the Ce-Zr-Co mixed oxides catalytic activity and stability. By comparing the X-ray diffraction before and after the test, it is possible to observe the reduction under the reactive mixture. In all samples, the diffraction pattern corresponding to $\mathrm{Co}_{3} \mathrm{O}_{4}$ in the spinel phase, as observed in the case of the fresh samples, is no longer observed after the catalytic test, proving the reduction of inserted cobalt to a lower oxidation state.

For the gold free CeZrCo catalyst (Figure 7a,b) a peak related with $\mathrm{CoO}$ is observed at $c a .2 \theta=43^{\circ}$, whereas for the gold containing CeZrCo catalyst (Figure 7b,c) the apparition of this peak is not obtained and no indication of a deeper reduction into $\mathrm{Co}^{0}$ is demonstrated by XRD. This difficulty could be attributed to a smaller particle size of cobalt in the reduced state, therefore not easily detectable but most probably, it corresponds to a higher degree of dispersion due to the presence of gold. It is possible to state the reduction of the outer cobalt structure that occurred, as based on the observation of the $\mathrm{Co}_{3} \mathrm{O}_{4}$ peak decreasing. However, the reduction of the cobalt inserted in the structure was not obtained since no changes in the fluorite structure oxide peak diffraction were observed. In respect to the gold stability, it seems that sintering under the reactive mixture during the catalytic test did not occur, since no remarkable changes in gold corresponding structure are observed. 
Figure 7. X-Ray Diffractograms of catalysts, before and after ethanol steam reforming, test of: (a) CeZrCo-A; (b) Au/CeZrCo-A; (c) CeZrCo-B; (d) Au/CeZrCo-B.

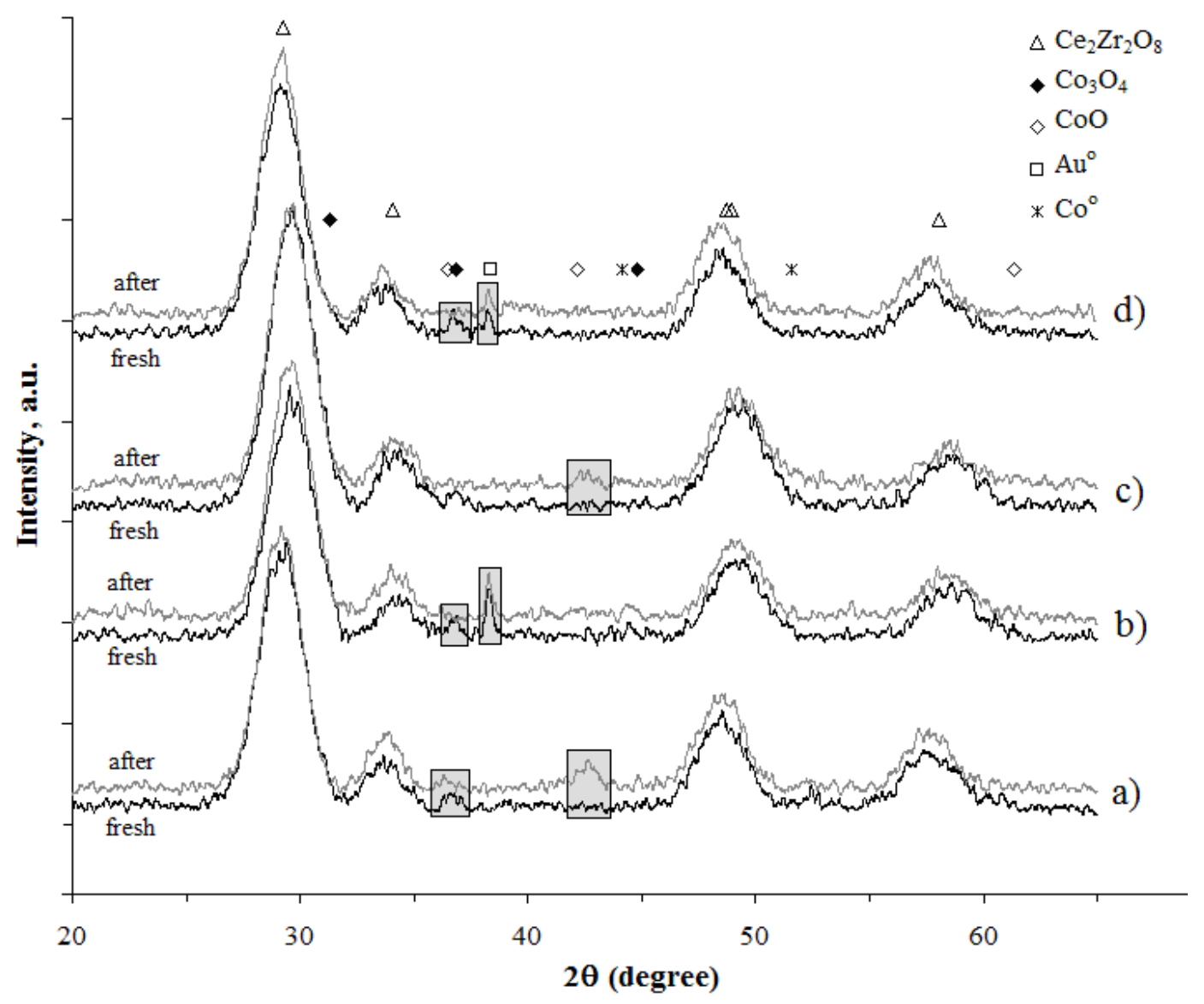

\section{Conclusions}

Two CeZrCo mixed oxides; $\mathrm{Ce}_{\mathrm{w}} \mathrm{Zr}_{\mathrm{y}} \mathrm{Co}_{0.9} \mathrm{O}_{8-\delta}(\mathrm{x}+\mathrm{y}=3.1)$, synthesized by a pseudo sol-gel like method lead to a partial cobalt integration in the fluorite lattice with high homogeneity at nanoscale level, which is influenced by $\mathrm{Ce} / \mathrm{Zr}$ ratio, producing a cobalt segregation as $\mathrm{Co}_{3} \mathrm{O}_{4}$.

The presence of gold affects the degree of the insertion of cobalt, generating a modification in the fluorite oxide structure and resulting in a different profile of reduction $v s$. temperature. This effect is strictly dependent on the $\mathrm{Ce} / \mathrm{Zr}$ ratio.

The $\mathrm{CeZrCo}$ and $\mathrm{Au} / \mathrm{CeZrCo}$ mixed oxides are effective catalysts to transform carbon monoxide into carbon dioxide and ethanol into hydrogen, even at low temperatures. The gold-containing samples present the best catalytic activity in both reactions, which is ascribed to the modification in the crystalline structure of fluorite type oxides, with a generation of oxygen vacancies, an increase of oxygen mobility and active phases which therefore become more easily reduced producing a large number of active sites.

\section{References}

1. Prince, D. Energy and human evolution. Popul. Environ. 1978, 16, 301.

2. International Energy Agency World Energy Outlook; Internaltional Enery Agency: Paris, France, 2009. Available online: http://www.worldenergyoutlook.org/ (accessed on 1 November 2011). 
3. Chum, H.L.; Evered, R.P. Biomass and renewable fuels. Fuel Process. Technol. 2001, 71, 187-195.

4. Haryanto, A.; Fernando, S.; Murali, N.; Adhikari, S. Current status of hydrogen production techniques by steam reforming of ethanol: A review. Energy Fuels 2005, 19, 2098-2116.

5. Ramírez de la Piscina, P.; Homs, N. Use of biofuels to produce hydrogen (reformation processes). Chem. Soc. Rev. 2008, 37, 2459-2467.

6. Fatsikostas, A.N.; Verykios, X.E. Reaction network of steam reforming of ethanol over Ni-based catalysts. J. Catal. 2004, 225, 439-452.

7. Benito, M.; Padilla, R.; Errano-Lotina, A.S.; Rodríguez, L.; Brey, J.J.; Daza, L. The role of surface reactions on the active and selective catalyst design for bioethanol steam reforming. J. Power Sources 2009, 192, 158-164.

8. Song, H.; Zhang, L.; Ozkan, U.S. Investigation of the reaction network in ethanol steam reforming over supported cobalt catalysts. Ind. Eng. Chem. Res. 2010, 49, 8984-8989.

9. Vaidya, P.D.; Rodrigues, A.E. Insight into steam reforming of ethanol to produce hydrogen for fuel cells. Chem. Eng. J. 2006, 117, 39-49.

10. Ni, M.; Leung, Y.C.; Leung, M.K.H. A review on reforming bio-ethanol for hydrogen production. Int. J. Hydrog. Energy 2007, 32, 3238-3247.

11. Vizcaíno, A.J.; Carrero, A.; Calles, J.A. Hydrogen production by ethanol steam reforming over Cu-Ni supported catalysts. Int. J. Hydrog. Energy 2007, 32, 1450-1461.

12. Vizcaíno, A.J.; Arena, P.; Baronetti, G.; Carrero, A.; Calles, J.A.; Laborde, M.A.; Amadeo, N. Ethanol steam reforming on $\mathrm{Ni} / \mathrm{Al}_{2} \mathrm{O}_{3}$ catalysts: Effect of $\mathrm{Mg}$ addition. Int. J. Hydrog. Energy 2008, 33, 3489-3492.

13. Sánchez-Sánchez, M.C.; Navarro, R.M.; Fierro, J.L.G. Ethanol steam reforming over La, Zr and Mg catalysts: Influence of support on the hydrogen production. Int. J. Hydrog. Energy 2007, 32, $1462-1471$.

14. Mariño, F.; Baronetti, G.; Jobbagy, M.; Laborde, M. Cu-Ni-K/ $\gamma-\mathrm{Al}_{2} \mathrm{O}_{3}$ supported catalysts for ethanol steam reforming Formation of hydrotalcite-type compounds as a result of metal-support interaction. Appl. Catal. A 2003, 238, 41-54.

15. Llorca, J.; Homs, N.; Sales, J.; Ramirez de la Piscina, P. Efficient Production of hydrogen over supported cobalt catalysts from ethanol steam reforming. J. Catal. 2002, 209, 306-317.

16. Frusteri, F.; Freni, S.; Spadaro, L.; Chiodo, V.; Bonura, G.; Donato, S.; Cavallaro, S. $\mathrm{H}_{2}$ production for $\mathrm{MC}$ fuel cell by steam reforming of ethanol over $\mathrm{MgO}$ supported $\mathrm{Pd}, \mathrm{Rh}, \mathrm{Ni}$ and Co catalysts. Catal. Commun. 2004, 5, 611-615.

17. Pereira, E.B.; Homs, N.; Martí, S.; Fierro, J.L.G.; Ramírez de la Piscina, P. Oxidative steam-reforming of ethanol over $\mathrm{Co} / \mathrm{SiO}_{2}, \mathrm{Co}-\mathrm{Rh} / \mathrm{SiO}_{2}$ and $\mathrm{Co}-\mathrm{Ru} / \mathrm{SiO}_{2}$ catalysts: Catalytic behavior and deactivation/regeneration processes. J. Catal. 2008, 257, 206-214.

18. Le Valant, A.; Bion, N.; Can, F.; Duprez, D.; Epron, F. Preparation and characterization of bimetallic $\mathrm{Rh}-\mathrm{Ni} / \mathrm{Y}_{2} \mathrm{O}_{3}-\mathrm{Al}_{2} \mathrm{O}_{3}$ for hydrogen production by raw bioethanol steam reforming: influence of the addition of nickel on the catalyst performances and stability. Appl. Catal. B 2010, 97, 72-81.

19. Birot, A.; Epron, F.; Descorme, C.; Duprez, D. Ethanol steam reforming over $\mathrm{Rh} / \mathrm{Ce}_{\mathrm{x}} \mathrm{Zr}_{1-\mathrm{x}} \mathrm{O}_{2}$ catalysts: Impact of the $\mathrm{CO}-\mathrm{CO}_{2}-\mathrm{CH}_{4}$ interconversion reactions on the $\mathrm{H}_{2}$ production. Appl. Catal. B 2008, 79, 17-25. 
20. Srinivas, D.; Satyanarayana, C.V.V.; Potdar, H.S.; Ratnasamy, P. Structural studies on $\mathrm{NiO}-\mathrm{CeO}_{2}-\mathrm{ZrO}_{2}$ catalysts for steam reforming of ethanol. Appl. Catal. A 2003, 246, 323-334.

21. Comas, J.; Mariño, F.; Laborde, M.; Amadeo, N. Bio-ethanol steam reforming on $\mathrm{Ni} / \mathrm{Al}_{2} \mathrm{O}_{3}$ catalyst. Chem. Eng. J. 2004, 98, 61-68.

22. Graschinsky, C.; Laborde, M.; Amadeo, N.; Le Valant, A.; Bion, N.; Epron, F.; Duprez, D. Ethanol steam reforming over $\mathrm{Rh}(1 \%) \mathrm{MgAl}_{2} \mathrm{O}_{4} / \mathrm{Al}_{2} \mathrm{O}_{3}$ : A kinetic study. Ind. Eng. Chem. Res. 2010, 49, 12383-12389.

23. Vargas, J.C.; Sternenberg, F.; Roger, A.C.; Kiennemann, A. Steam reforming of bioethanol on $\mathrm{Coo} / \mathrm{Ce}-\mathrm{Zr}-\mathrm{Co}$ and $\mathrm{Coo} / \mathrm{Ce}-\mathrm{Zr}$ catalyst. A comparison between cobalt integration and cobalt impregnation. Chem. Eng. Trans. 2004, 4, 247-252.

24. Vargas, J.C.; Vanhaecke, E.; Roger, A.C.; Kiennemann, A. Hydrogen production by ethanol steam reforming. Study of cobalt-doped Ce-Zr catalysts. Stud. Surf. Sci. Catal. 2004, 147, $115-120$.

25. Vargas, J.C.; Libs, S.; Roger, A.C.; Kiennemann, A. Study of Ce-Zr-Co fluorite-type oxide as catalysts for hydrogen production by steam reforming of bioethanol. Catal. Today 2005, 107-108, 417-425.

26. Romero-Sarria, F.; Vargas, J.C.; Roger, A.C.; Kiennemann, A. Hydrogen production by steam reforming of ethanol: Study of mixed oxide catalysts $\mathrm{Ce}_{2} \mathrm{Zr}_{1.5} \mathrm{Me}_{0.5} \mathrm{O}_{8}$ : Comparison of $\mathrm{Ni} / \mathrm{Co}$ and effect of Rh. Catal. Today 2008, 133-135, 149-153.

27. Araque, M.; Vargas, J.C.; Zimmermann, Y.; Roger, A.C. Study of a CeZrCoRh mixed oxide for hydrogen production by ethanol steam reforming. Int. J. Hydrog. Energy 2011, 36, 1491-1502.

28. Sheng, P.-Y.; Bowmaker, G.A.; Idriss, H. The reactions of ethanol over $\mathrm{Au} / \mathrm{CeO}_{2}$. Appl. Catal. A 2004, 261, 171-181.

29. Haruta, M.; Kobayashi, T.; Sano, H.; Yamada, N. Novel gold catalysts for the oxidation of carbon monoxide at a temperature far below $0{ }^{\circ} \mathrm{C}$. Chem. Lett. 1987, 2, 405-408.

30. Azizi, Y.; Pitchon, V.; Petit, C. Effect of support parameters on activity of gold catalysts: Studies of $\mathrm{ZrO}_{2}, \mathrm{TiO}_{2}$ and mixture. Appl. Catal. A 2010, 385, 170-177.

31. Ivanova, S.; Petit, C.; Pitchon, V. A new preparation method for the formation of gold nanoparticles on an oxide support. Appl. Catal. A 2004, 267, 191-201.

32. Ivanova, S.; Pitchon, V.; Petit, C. Application of the direct exchange method in the preparation of gold catalysts supported on different oxide materials. J. Mol. Catal. A 2006, 256, 278-283.

33. Fu, Q.; Deng, W.; Saltsburg, H.; Flytzani-Stephanopoulos, M. Activity and stability of low-content gold-cerium oxide catalysts for the water-gas shift reaction. Appl. Catal. B 2005, 56, $57-68$.

34. Venezia, A.M.; Pantaleo, G.; Longo, A.; Di Carlo, G.D.; Casaletto, M.P.; Liotta, F.L.; Deganello, G.J. Relationship between structure and CO oxidation activity of ceria-supported gold catalysts. J. Phys. Chem. B 2005, 109, 2821-2827.

35. Klug, H.P.; Alexander, L.E. X-Ray Diffraction Procedure for Polycrystalline and Amorphous Materials, 2nd ed.; Wiley: New York, NY, USA, 1974.

36. Ivanova, S. Formation de Nanoparticules d'or Supportées: De la Préparation à la Réactivité catalytique. PhD Thesis, University of Strasbourg, Strasbourg, France, 2004. 
37. Ambroise, E.; Courson, C.; Roger, A.C.; Kiennemann, A.; Blanchard, G.; Rousseau, S.; Carrier, X.; Marceau, E.; La Fontaine, C.; Villain, F. Exhaust gas recirculation for on-board hydrogen production by isooctane reforming: Comparison of performances of metal/ceria-zirconia based catalysts prepared through pseudo sol-gel or impregnation methods. Catal. Today 2010, 154, 133-141.

38. Mizuno, T.; Nakajima, T. TPR studies on steam reforming of 2-propanol on $\mathrm{Rh} / \mathrm{Al} 2 \mathrm{O} 3, \mathrm{Ru} / \mathrm{Al}_{2} \mathrm{O}_{3}$ and $\mathrm{Pd} / \mathrm{Al}_{2} \mathrm{O}_{3}$. React. Kinet. Catal. Lett. 2003, 78, 315-324.

39. Aupretre, F.; Descormes, C.; Duprez, D. Hydrogen production for fuel cells from the catalytic ethanol steam reforming. Topics Catal. 2004, 30-31, 487-491.

(C) 2012 by the authors; licensee MDPI, Basel, Switzerland. This article is an open access article distributed under the terms and conditions of the Creative Commons Attribution license (http://creativecommons.org/licenses/by/3.0/). 